\title{
Is Earnings Information Superior to Net Income as a Measure of Future Earnings? A Study on Accruals and Real Earnings Management
}

\author{
Yung-Chuan Lee ${ }^{1} \&$ Cheng-Chang $\mathrm{Lu}^{1}$ \\ ${ }^{1}$ Department of International Business, Asia University, Taichung, Taiwan \\ Correspondence: Yung-Chuan Lee, Department of International Business, Asia University, 500 Liufeng Road, \\ Wufeng, Taichung, Taiwan. Tel: 886-4-2332-3456 ext. 5561. E-mail: leeyc@asia.edu.tw
}

Received: December 16, 2014

Accepted: January 8, 2015

Online Published: January 14, 2015

doi:10.5430/ijfr.v6n1p119

URL: http://dx.doi.org/10.5430/ijfr.v6n1p119

\begin{abstract}
This study examines the incremental information content of components of earnings by regressing future net income of earnings' components in a series of multivariate models. We find that the components of operating cash flow and accruals provide more information to effectively predict future profitability, particularly when we dismantles financial measurements into various combinations of operating cash flow and accrual-based components. However, the components of real earnings management provide less information of future profitability. We observe that the more informative the information content of earnings is, the more precise the prediction of future profitability can be.
\end{abstract}

Keywords: accruals earnings management, real activities manipulation, earnings information

\section{Introduction}

Financial reporting reveals information for readers of financial statements to understand each enterprise's operational performance, and thus we often regard it as a useful reference for investment decisions. For those readers of financial statements, earning is a critical indicator that measures a firm's performance because it contains information about managerial capabilities and identifies managers' various contributions to corporate profits. Therefore, the informative characteristic of earning intensifies executives' incentive to engage in earnings management. According to Healy and Wahlen (1999), earnings management refers to how managers manipulate financial figures and disclosures, such as through flexibility of accepted accounting principle, recognition of transactions occurrence, changes of accounting methods, and ability to dominate stakeholders' cognition of their firms' financial performance. This is because firms are required to provide disclosure under regulation in financial statements, footnotes and regulatory filings. On the other hand, some executives grasp any possible chance of voluntary communication, including management forecasts, press releases and other corporate reports to manipulate their target audience.

Nevertheless, an asymmetry of information exists among managers, shareholders and readers of financial reports. At its best, managerial manipulation could enhance earnings' informativeness, but to some extent it could also mislead stakeholders' cognition by strategically releasing enterprises' confidential information under executives' discretions to match financial targets. The reason behind such behavior is that in modern capital market, the reward for managers relies on the financial performance of corporations. For example, agency theory (Jensen and Mickling, 1976) has pointed out that managers have various incentives to manipulate financial decisions at the expense of shareholders. The misalignment of managers' intents and shareholders' interests occasionally induces earning manipulation in financial figures through managers' discretion; thereby it creates possibilities of distorting financial information.

The literature on financial statement analysis (White, Sondhi and Fried, 1998) defines income as the sum of cash flows and changes in net assets. Determining which cash flows and changes in asset values should be included in income and the timing to do so is based on accounting rules and principles under generally accepted accounting principles (GAAP). With a few exceptions, the standard accounting process only recognizes cash and value changes occur in actual transactions, which is regarded as an accrual concept.

In regard to the accrual concept, accounting income represents a selective recognition of both actual cash flows in the current period and changes in asset values. In other words, earning under the accrual concept provides a measure of one firm's current operating performance not solely relied upon actual current-period cash flows. Cash inflows and 
outflows are regarded as income in appropriate accounting periods as delivered goods and services rather than as incurred cash and expenditures. The accrual accounting concept allows preparers of financial statements to decide the proper timing of recognizing the revenues and consequential expenses of cash flows and other events. Sloan (1996) states that the discretionary decisions of recognizing revenues and expenses in selective periods along with those actually received or spent cash have corollary effects on the balance sheets and income statements. Thus, the timing selection and recognized components best indicate the firm's present and persistent abilities to generate future cash flows.

In addition, Sloan's research underlines the earnings performance, suggesting that accrual components of earning display more continuation of future earnings than cash flow components of earnings. Sloan argues that participants of stock market often fail to distinct between the characteristics of accrual and cash flow components of earnings. The results indicate negative relations between the levels of accruals under managerial discretion and future stock returns. Accordingly, investigating earning components under the accrual concept provides a means of understanding the executive's perspective of future earnings.

Xie (2001) examine whether stock market rationally reflects these implications of accruals on enterprise's one-year-ahead earnings performance. Xie's study shows that the market overestimates the persistence of accrual components and overprices those stocks associated with abnormal accruals. Subramanyam (1996) demonstrate that abnormal accruals positively relate with future earnings. Also, Dechow (2006) states that abnormal accruals of special items improve the persistence of earnings in firms with high level of accruals while reduce earnings persistence in firms with low level of accruals. The findings of researches suggest that firms with high level of positive accruals invest in assets, generate sales, and expand their businesses (Kothari et al., 2005; Dechow et al., 2010; Feng et al., 2011). Due to the conservative concerns of accounting principles, the balance sheets of these firms do not provide precise information about future earnings. Instead, many cash outflows occur immediately in these investments. Thus, negative transitory cash flows are likely to happen in those firms associated with high level of accruals.

Prior studies focus on managerial discretion of accruals; however, they ignored the fact that executives can also affect cash flows to meet certain earnings targets by manipulating real activities regarded as management discretions deviate business actions from normal practices to meet certain earnings thresholds or benchmarks. The first reason why managers may want to engage in real activities manipulation is that aggressive accruals discretions face higher risks of regulatory scrutiny and litigation. Second, the manager owns the power of real activities management, whereas accruals-based accounting choices must conduct at the end of fiscal year or in each quarter. Furthermore, after the passage of Sarbanes-Oxley Act in 2002 (U.S. House of Representatives 2002) (hereafter SOX), executives had less incentives to use their discretions manipulating earning and they tended to be more conservative when encountering increased regulatory liability.

Aono \& Guan (2007) and Zhou (2007) observe that the Sarbanes-Oxley Act (SOX) was successful in deterring accrual-based earnings management. Similarly, Lobo and Zhou (2006) reported that firms used less discretionary accruals after SOX. Observing the issue from another perspective, Cohen, Dey, and Lys (2008) document a significant increase in real earnings management activities in the post-SOX era, which was concurrent with the decline in accrual based ones. These researches suggest that firms may be switching from accrual-based to real-activities earnings management methods after the passage of SOX.

In the research literature, Cohen and Zarowin (2010), Graham et al. (2005), Healy and Wahlen (1999), Fudenberg and Tirole (1995), and Dechow and Skinner (2000) have noticed such inclinations that managers already preferred real earnings management activities when compared to accrual-based earnings management. This has been the case since auditors and regulators are unlikely to scrutinize real management activities, and thus there is a great probability that inspectors fail to detect abnormal activities which can bring significant economic benefits to the firm. Moreover, Cohen et al. (2008) find that managers have shifted away from accrual to real earnings management in the post Sarbanes-Oxley Act (SOX) period; which is consistent with the conjectures made by Graham et al. (2005) and Zang (2012). These research results imply that, following highly publicized accounting scandals took place in the post-SOX period, managers still find the need which is even greater than in previous periods to prevent auditors from detecting suspicious accrual-based earnings managing activities which induce managers to shift to real earnings management activities.

Prior studies (Baber et al., 1991; Bens et al., 2002, 2003; Dechow and Sloan, 1991; Bushee, 1998; Badertscher, 2011) of real activities management concentrate on how discretionary reduction of operational expenditures reduces reported expenses. For instance, Graham et al (2005) suggest that 80 percent of surveyed managers deploy price 
discounts to increase sales in specific time periods, excessive inventory to loIr reported COGS, as Ill as curtailment of research, development, advertising, and maintenance expenditures.

However, Field et al. (2001) caution against examining only one technique of earnings management for not sufficiently explaining the overall effect of earning management activities on the prediction of earnings. In the same vein, Zang (2012) provides evidence that managers mutually use accrual-based earning management and real activities manipulation to deliver earnings, responding to their relative costs. Hence, Zang argues that managers would adjust the frequency of using accrual-based earnings management according to the realized extent of real activities manipulation. In light of the studies mentioned above, researchers can no longer achieve (definitive) conclusions by solely investigating either type of earning management activities in isolation. This study will investigate the components of earnings by dismantling_financial figures of accrual-based earnings and real activities earnings components into a series of different combinations to examine whether studying one firm's earnings managing method can reveal more information about this firm, which enables investors to predict future profitability effectively.

\section{Research Design}

\subsection{Sample}

The data of this research come from the Taiwan Economic Journal (TEJ) database. The sample consists of firms listed in the Taiwan Stock Exchange during 2002-2011. To estimate discretionary accruals and abnormal operating cash flows, the study requires a minimum of 6 observations for each pair of industry and calendar year. The analysis excludes firm-year observations (1) with fewer than six observations in any industry and year combination; (2) missing beginning of year total assets or with insufficient data to calculate discretionary accruals and abnormal operating cash flow defined in the following section; (3) missing monthly stock returns; (4) whose operating cash flows, discretionary accruals, or nondiscretionary accruals are more than three standard deviations away from their respective means; and (5) we also sort out firms in the banking industry because the nature of their financial reports is different from those of other industries. Accordingly, the available sample comprises of 6,476 firm-year observations which we demonstrate the sample distributions of related industries on Table 1. The evidence of $47.11 \%$ of electronic industry results from the consequence of industrial development in Taiwan.

Table 1. The sample distribution of related industry

\begin{tabular}{cccc}
\hline TSE industry code & Industries & No of firm-years & $\%$ of Sample \\
\hline M1100 & Cement & 70 & $1.08 \%$ \\
M1200 & Food & 199 & $3.08 \%$ \\
M1300 & Plastic & 209 & $3.23 \%$ \\
M1400 & Weaving & 458 & $7.08 \%$ \\
M1500 & Mechanical electric & 356 & $5.50 \%$ \\
M1600 & Wire/Cable & 120 & $1.85 \%$ \\
M1700 & Chemical & 350 & $5.41 \%$ \\
M1800 & Glass & 70 & $1.08 \%$ \\
M1900 & Paper making & 70 & $1.08 \%$ \\
M2000 & Steel & 277 & $4.28 \%$ \\
M2100 & Rubber & 90 & $1.40 \%$ \\
M2200 & Car & 44 & $0.68 \%$ \\
M2500 & Construction & 356 & $5.50 \%$ \\
M2600 & Transportation & 174 & $2.69 \%$ \\
M2700 & Tourism & 70 & $1.08 \%$ \\
M2900 & Department store & 100 & $1.54 \%$ \\
M9700 & Oil \& gas & 79 & $1.22 \%$ \\
M990 & Others & 332 & $5.13 \%$ \\
M2300 & Electronics & 3051 & $47.11 \%$ \\
Total & & 6476 & $100 \%$ \\
\hline
\end{tabular}




\subsection{Mearsurement of Variables}

\subsubsection{The Measurement of Nondiscretionary Accruals and Discretionary Accruals}

We use across-sectional model to calculate discretionary accruals of each year, estimating the model for every industry categorized by its 2-digit SIC code. Thus, my approach partially controls industry-wide changes in economic conditions that affect total accruals while allowing the coefficients to vary over time (DeFond and Jiambalvo, 1994; Kasznik, 1999; Kothari et al., 2005; Cohen et al., 2010; Dechow et al., 2010)). Our primary analysis model of discretionary accruals bases on the following cross-sectional model, which evaluates each 2 digit SIC-year grouping as follows.

In addition, this study employs a cross-sectional version of modified Jones model proposed by Dechow et al. (1995) to calculate nondiscretionary accruals. Please note that this model estimates nondiscretionary accruals as a function of change in net revenue and the levels of property, plant, and equipment. In this research, we define discretionary accruals as the difference between total accruals and nondiscretionary accruals.

For each 2 digit SIC-year grouping, we build our primary cross-sectional model of discretionary accruals via the following equations:

$$
\frac{\mathrm{ACCR}_{\mathrm{j}, \mathrm{t}}}{\mathrm{TA}_{\mathrm{j}, \mathrm{t}-1}}=\alpha_{1}\left[\frac{1}{\mathrm{TA}_{\mathrm{j}, \mathrm{t}-1}}\right]+\alpha_{2}\left[\frac{\Delta \mathrm{REV}_{\mathrm{j}, \mathrm{t}}}{\mathrm{TA} \mathrm{A}_{\mathrm{j}, \mathrm{t}-1}}\right]+\alpha_{3}\left[\frac{\mathrm{PPE}_{\mathrm{j}, \mathrm{t}}}{\mathrm{TA} \mathrm{A}_{\mathrm{j}, \mathrm{t}-1}}\right]+\mathrm{e}_{\mathrm{j}, \mathrm{t}}
$$

$\mathrm{ACCR}_{\mathrm{j}, \mathrm{t}}$ : total accruals for firm $\mathrm{j}$ in year $\mathrm{t}$.

$\mathrm{TA}_{\mathrm{j}, \mathrm{t}-1}$ : total assets for firm $\mathrm{j}$ in year $\mathrm{t}-1$.

$\triangle \mathrm{REV}_{\mathrm{j}, \mathrm{t}}$ : change in net revenue for firm $\mathrm{j}$ in year $\mathrm{t}$.

$\mathrm{PPE}_{\mathrm{j}, \mathrm{t}}$ : property, plant, and equipment for firm $\mathrm{j}$ in year $\mathrm{t}$.

The error term from Eq.(1) represents the discretionary component of accruals.

$$
\mathrm{NDAC}_{\mathrm{j}, \mathrm{t}}=\widehat{\alpha}_{1}\left[\frac{1}{\mathrm{TA}_{\mathrm{j}, \mathrm{t}-1}}\right]+\widehat{\alpha}_{2}\left[\frac{\Delta \mathrm{REV}_{\mathrm{j}, \mathrm{t}}}{\mathrm{TA}_{\mathrm{j}, \mathrm{t}-1}}\right]+\widehat{\alpha_{3}}\left[\frac{\mathrm{PPE}_{\mathrm{j}, \mathrm{t}}}{\mathrm{TA}_{\mathrm{j}, \mathrm{t}-1}}\right]
$$

$\mathrm{NDAC}_{\mathrm{j}, \mathrm{t}}$ : nondiscretionary accruals for firm $\mathrm{j}$ in year $\mathrm{t}$.

$$
\mathrm{DAC}_{\mathrm{j}, \mathrm{t}}=\frac{\mathrm{ACCR}_{\mathrm{j}, \mathrm{t}}}{\mathrm{TA}_{\mathrm{j}, \mathrm{t}-1}}-\widehat{\alpha}_{1}\left[\frac{1}{\mathrm{TA}_{\mathrm{j}, \mathrm{t}-1}}\right]-\widehat{\alpha}_{2}\left[\frac{\Delta \mathrm{REV}_{\mathrm{j}, \mathrm{t}}}{\mathrm{TA}_{\mathrm{j}, \mathrm{t}-1}}\right]-\widehat{\alpha_{3}}\left[\frac{\mathrm{PPE}_{\mathrm{j}, \mathrm{t}}}{\mathrm{TA}_{\mathrm{j}, \mathrm{t}-1}}\right]
$$

$\mathrm{DAC}_{\mathrm{j}, \mathrm{t}}$ : discretionary accruals for firm $\mathrm{j}$ in year $\mathrm{t}$.

\subsubsection{The Measurement of Abnormal and Normal Operating Cash Flow}

Most prior researches on earnings management aim at finding abnormal accruals. Indeed, managers have incentives to manipulate real activities during a year to meet certain earnings targets (Zang, 2012). In the surveys conducted by Dechow et al (2010), Roychowdhury (2006), Bruns and Merchant (1990) and Graham et al. (2005), financial executives express a greater willingness to manipulate earnings through real activities than accruals. With the primary objective of meeting certain earnings thresholds, managers may undertake real activities management actions that deviate from normal business practices.

Operating cash flow (OCF) is cash generated from normal operations of a business. Analysts consider operating cash flow important because it provides them insight into the health of core business or operations of a company. As an essential part of the Cash Flow Statement, the cash flows of operating activities, investing activities, and financing activities are segregated, so analysts can get a clear picture of the cash flows of a company's all activities. As in Roychowdhury's work (2006), we evaluate the abnormal degrees of operation cash flows to study the level of real activities manipulations, which usually turn out to be the three patterns listed below:

1). Managers accelerate sales at specific time through increasing price discounts or providing more lenient credit terms. Such discounts and lenient credit will temporarily increase sales volumes, but these phenomena are likely to disappear once the firm reverts to old prices. The additional sales will boost current period earnings, assuring investors that the margins are positive. Nevertheless, both price discounts and lenient credit terms will also result in lower cash flows in the current period.

2). Executives lower cost of goods sold through increasing production. Managers can boost the production more than necessary in order to accelerate earnings. When enterprises produce more units, they can spread the fixed overhead costs over a larger number of units, thus lowering fixed costs per unit. This strategy cuts reported cost of goods sold 
(COGS) and the firm can report higher operating margins. However, the firm will still involve in other productions, so holding costs will lead to higher annual production costs related to sales; given the firms' sales levels, they may lower operation cash flows respectively.

3). Decreases in discretionary expenses include advertising, research and development, and SG\&A expenses. Reducing such expenses will boost current period's earnings. It could also lead to higher current period cash flows (at the risk of lower future cash flows), if the firm generally paid such expenses in cash.

Our study relies on previous researches to develop variables of real earnings management activities. Similar to Roychowdhury's research (2006), we examine the level of real activities manipulations by testing the abnormal levels of cash flow from operations (OCF), discretionary expenses, and production costs. Subsequent studies, such as Zang's (2012) and Gunny's (2010), provide evidence of the construct validity of these variables. we will focus on the three manipulation methods as follws and their impacts on the three variables listed above.

First, Graham et al. (2005) survey OCFs and argue that managers often engage in real earnings management in order to meet earnings expectations. They note that in the post-SOX environment, managers may prefer to shift from taking accounting actions, such as accounting policies and estimates, to real actions to manage earnings. This is because after SOX, accounting actions may be subject to increased scrutiny from auditors and regulators. Graham et al. estimate that managers' attempts to take earnings management have deprived 150 billion of value and thus it is important to identify mechanisms that may potentially constrain real earnings management.

Second, Roychowdhury (2006) defines real activities manipulation as management actions that departures from normal operational practices. These departures do not necessarily contribute to firm value even though they enable managers to meet reporting goals." Roychowdhury's study investigates patterns in cash flow from operations (OCF), discretionary expenses, and production costs and then hypothesizes that manipulating real activities would result in three outcomes: abnormally low cash flow from operations, or unusually low discretionary expenses, such as advertising or research and development expenses, or unusually high production costs.

Roychowdhury's arguments rely on the fact that real earnings management manifests through sales manipulation, reduction of discretionary expenditures, or overproduction. If a firm tries to achieve better sales by providing price discounts, this will lead to lower cash flows over the normal condition of sales; accordingly such discount will bring out lower cash flow from operations. Thus, lower cash flow from operations is a potential characteristic of real earnings management firms. In addition, firms can manage earnings by reducing discretionary expenses such as $\mathrm{R} \& \mathrm{D}$, advertising, and maintenance.

Because the fees for these activities are paid in the same period they incur, a reduction of their spending will directly contribute to income increase. As a result, another potential characteristic of firms doing real earnings manipulation is their lower discretionary expenses. Last, firms which report higher earnings may lower their cost of goods sold by the means of overproduction. By producing more than necessary, these firms can spread fixed overhead costs over a larger number of units, which will cause a decrease in total cost per unit. To put it in another way, when the cost of goods sold declines, the income will rise. Therefore, the final potential characteristic of real earnings management firms is that they exhibit high production costs.

Equation (4) represents the components of operating cash flow:

$$
\mathrm{OCF}_{\mathrm{j}, \mathrm{t}}=\mathrm{FFO}_{\mathrm{j}, \mathrm{t}}-\Delta \mathrm{CA}_{\mathrm{j}, \mathrm{t}}+\Delta \mathrm{CASH}_{\mathrm{j}, \mathrm{t}}+\Delta \mathrm{CL}_{\mathrm{j}, \mathrm{t}}-\Delta \mathrm{STDEBT}_{\mathrm{j}, \mathrm{t}}
$$

$\mathrm{FFO}_{\mathrm{j}, \mathrm{t}}$ : funds from operations for firm $\mathrm{j}$ in year $\mathrm{t}$.

$\triangle \mathrm{CA}_{\mathrm{j}, \mathrm{t}}$ : change in current assets for firm $\mathrm{j}$ in year $\mathrm{t}$.

$\triangle \mathrm{CASH}_{\mathrm{j}, \mathrm{t}}$ : change in cash and short-term investments for firm $\mathrm{j}$ in year $\mathrm{t}$.

$\Delta C \mathrm{~L}_{\mathrm{j}, \mathrm{t}}$ : change in current liabilities for firm $\mathrm{j}$ in year $\mathrm{t}$.

$\triangle$ STDEBT $_{\mathrm{j}, \mathrm{t}}$ : change in short term debt for firm $\mathrm{j}$ in year $\mathrm{t}$.

Third, Roychowdhury (2006) suggests that price discounts, channel stuffing, and overproduction all demonstrate negative effects on contemporaneous abnormal OCF, while reduction of discretionary expenditures brings out a positive effect. Thus, the net effect on abnormal OCF is difficult to estimate. Accordingly, using the model developed by Dechow et.al. (1998), we first generate the normal levels of OCF, discretionary expenses, and production costs as in Roychowdhury's study. we display normal OCF as a linear function of sales and changes in sales. To estimate this model, we run the following cross-sectional regression for each industry and year of my Taiwan-based data: 


$$
\begin{array}{r}
\frac{\mathrm{OCF}_{\mathrm{j}, \mathrm{t}}}{\mathrm{TA}_{\mathrm{j}, \mathrm{t}-1}}=\beta_{1}\left[\frac{1}{\mathrm{TA}_{\mathrm{j}, \mathrm{t}-1}}\right]+\beta_{2}\left[\frac{\text { Sale }_{\mathrm{j}, \mathrm{t}}}{\mathrm{TA}_{\mathrm{j}, \mathrm{t}-1}}\right]+\beta_{3}\left[\frac{\Delta \text { Sale }_{\mathrm{j}, \mathrm{t}}}{\mathrm{TA}_{\mathrm{j}, \mathrm{t}-1}}\right]+\varepsilon_{\mathrm{j}, \mathrm{t}} \\
\mathrm{NOCF}_{\mathrm{j}, \mathrm{t}}=\widehat{\beta_{1}}\left[\frac{1}{\mathrm{TA}_{\mathrm{j}, \mathrm{t}-1}}\right]+\widehat{\beta_{2}}\left[\frac{\mathrm{Sale}_{\mathrm{j}, \mathrm{t}}}{\mathrm{TA}_{\mathrm{j}, \mathrm{t}-1}}\right]+\widehat{\beta_{3}}\left[\frac{\Delta \mathrm{Sale}_{\mathrm{j}, \mathrm{t}}}{\mathrm{TA}_{\mathrm{j}, \mathrm{t}-1}}\right]
\end{array}
$$

$\mathrm{NOCF}_{\mathrm{j}, \mathrm{t}}$ : cash flow from operations before real activities manipulation for firm $\mathrm{j}$ in year $\mathrm{t}$.

Abnormal OCF is actual OCF minus the normal level of OCF calculated using the estimated coefficient from Eq. (5).

$$
\mathrm{AOCF}_{\mathrm{j}, \mathrm{t}}=\frac{\mathrm{OCF}_{\mathrm{j}, \mathrm{t}}}{\mathrm{TA}_{\mathrm{j}, \mathrm{t}-1}}-\widehat{\beta_{1}}\left[\frac{1}{\mathrm{TA}_{\mathrm{j}, \mathrm{t}-1}}\right]-\widehat{\beta_{2}}\left[\frac{\mathrm{Sale}_{\mathrm{j}, \mathrm{t}}}{\mathrm{TA}_{\mathrm{j}, \mathrm{t}-1}}\right]-\widehat{\beta_{3}}\left[\frac{\Delta \mathrm{Sale}_{\mathrm{j}, \mathrm{t}}}{\mathrm{TA}_{\mathrm{j}, \mathrm{t}-1}}\right]
$$

$\mathrm{AOCF}_{\mathrm{j}, \mathrm{t}}$ : abnormal cash flow from real activities manipulation for firm $\mathrm{j}$ in year $\mathrm{t}$.

Summing (6) and (7), this research decomposes operating cash flow (OCF) into manipulated operating cash flow (AOCF) and operating unmanipulated cash flows (NOCF) as in equation (8).

$$
\mathrm{OCF}_{\mathrm{j}, \mathrm{t}}=\mathrm{NOCF}_{\mathrm{j}, \mathrm{t}}+\mathrm{AOCF}_{\mathrm{j}, \mathrm{t}}
$$

Through the above analysis, this study divides the reported earnings into different elements. With better control of these elements, we hope to further verify whether the information content of earnings could help explaining a company's future profits.

\subsection{Comparison Explanatory Power of Earnings Components}

For net income, we use the definitions by Subramanyam (1996) and Xie (2001), which is the sum of accruals and cash flow from operations.

$\mathrm{NI}_{\mathrm{j}, \mathrm{t}}$ : net income for firm $\mathrm{j}$ in year $\mathrm{t}$.

$$
\mathrm{NI}_{\mathrm{j}, \mathrm{t}}=\mathrm{OCF}_{\mathrm{j}, \mathrm{t}}+\mathrm{ACCR}_{\mathrm{j}, \mathrm{t}}
$$

A business entity produces a product or provides service, and the analysts want to know if its core business produces sufficient cash flow 1) to pay its operating expenses; 2) to provide capital for its future growth (investment activities); 3 ) to meet the entity's interest and debt requirement, and 4) to pay dividends or to repurchase shares from stakeholders (financing activities). we exclude financing and investment activities because this research intentionally segregates cash flow from operations from other earnings components for the purpose of evaluating the health of the normal operations or core business.

Operating cash flow will perform as the most important measure which provides evidence to evaluate the health of a company's core business operations. Accordingly, we sum (3) and (2) and show the components of accruals as follows:

$$
\mathrm{ACCR}_{\mathrm{j}, \mathrm{t}}=\mathrm{NDAC}_{\mathrm{j}, \mathrm{t}}+\mathrm{DAC}_{\mathrm{j}, \mathrm{t}}
$$

After separating the discretionary and nondiscretionary components of accruals, we determine nondiscretionary income (NDNI) as follows:

$$
\mathrm{NDNI}_{\mathrm{j}, \mathrm{t}}=\mathrm{OCF}_{\mathrm{j}, \mathrm{t}}+\mathrm{NDAC}_{\mathrm{j}, \mathrm{t}}
$$

$\mathrm{NDNI}_{\mathrm{j}, \mathrm{t}}$ : nondiscretionary income for firm $\mathrm{j}$ in year $\mathrm{t}$.

$$
\mathrm{NMNI}_{\mathrm{j}, \mathrm{t}}=\mathrm{NOCF}_{\mathrm{j}, \mathrm{t}}+\mathrm{NDAC}_{\mathrm{j}, \mathrm{t}}
$$

$\mathrm{NMNI}_{\mathrm{j}, \mathrm{t}}$ : nonmanipulated net income

Accordingly, we can decompose one firm's earnings into the following six different combinations of components:

$$
\begin{aligned}
\mathrm{NI}_{\mathrm{j}, \mathrm{t}} & =\mathrm{OCF}_{\mathrm{j}, \mathrm{t}}+\mathrm{ACCR}_{\mathrm{j}, \mathrm{t}} \\
& =\mathrm{OCF}_{\mathrm{j}, \mathrm{t}}+\mathrm{NDAC}_{\mathrm{j}, \mathrm{t}}+\mathrm{DAC}_{\mathrm{j}, \mathrm{t}} \\
& =\mathrm{ACCR}_{\mathrm{j}, \mathrm{t}}+\mathrm{AOCF}_{\mathrm{j}, \mathrm{t}}+\mathrm{NOCF}_{\mathrm{j}, \mathrm{t}} \\
& =\mathrm{AOCF}_{\mathrm{j}, \mathrm{t}}+\mathrm{NOCF}_{\mathrm{j}, \mathrm{t}}+\mathrm{NDAC}_{\mathrm{j}, \mathrm{t}}+\mathrm{DAC}_{\mathrm{j}, \mathrm{t}} \\
& =\mathrm{NMNI}_{\mathrm{j}, \mathrm{t}}+\mathrm{AOCF}_{\mathrm{j}, \mathrm{t}}+\mathrm{DAC}_{\mathrm{j}, \mathrm{t}} \\
& =\mathrm{NDNI}_{\mathrm{j}, \mathrm{t}}+\mathrm{DAC}_{\mathrm{j}, \mathrm{t}}
\end{aligned}
$$

First of all, this study applies univariate regressions for 8 alternative firm performance measures: NI, OCF, NDAC, DAC, NDNI, AOCF, NOCF and NMNI. According to the equations from (13-1) to (13-6), we divide these 
performance measures into 6 compositions of net income components as shown on Table 2. Their power of prediction is calculated by adjust $\mathrm{R}^{2}$. (All variables are deflated by total assets at the beginning of the period.)

We regress the components of earnings and compares the relative magnitudes of their coefficients to investigate the explanatory power of these components in forecasting future profitability. Then our study examines the incremental information content of the compositions of net income components via conducting a regression of future net income on earnings' components in multivariate models. In addition, the purpose of applying a Vuong test is to compare the predicted probabilities of two models.

Table 2. Information of net income components and models

\begin{tabular}{|c|c|c|}
\hline Model & Equation & $\begin{array}{l}\text { Information of net income } \\
\text { components }\end{array}$ \\
\hline 1 & $\mathrm{NI}_{\mathrm{j}, \mathrm{t}+1}=\beta_{0}+\beta_{1} \mathrm{OCF}_{\mathrm{j}, \mathrm{t}}+\beta_{2} \mathrm{ACCR}_{\mathrm{j}, \mathrm{t}}+\epsilon_{\mathrm{j}, \mathrm{t}}$ & operating cash flow \\
\hline 2 & $\begin{array}{r}\mathrm{NI}_{\mathrm{j}, \mathrm{t}+1}=\beta_{0}+\beta_{1} \mathrm{OCF}_{\mathrm{j}, \mathrm{t}}+\beta_{2} \mathrm{NDAC}_{\mathrm{j}, \mathrm{t}}+\beta_{3} \mathrm{DAC}_{\mathrm{j}, \mathrm{t}}+\epsilon_{\mathrm{j}, \mathrm{t}} \\
(13-2)\end{array}$ & $\begin{array}{l}\text { operating cash flow } \\
\text { accruals manipulation }\end{array}$ \\
\hline 3 & $\mathrm{NI}_{\mathrm{j}, \mathrm{t}+1}=\beta_{0}+\beta_{1} \mathrm{DAC}_{\mathrm{j}, \mathrm{t}}+\beta_{2} \mathrm{NDNI}_{\mathrm{j}, \mathrm{t}}+\epsilon_{\mathrm{j}, \mathrm{t}}$ & accruals manipulation \\
\hline 4 & $\mathrm{NI}_{\mathrm{j}, \mathrm{t}+1}=\beta_{0}+\beta_{1} \mathrm{NDAC}_{\mathrm{j}, \mathrm{t}}+\beta_{2} \mathrm{DAC}_{\mathrm{j}, \mathrm{t}}+\beta_{3} \mathrm{AOCF}_{\mathrm{j}, \mathrm{t}}+\beta_{4} \mathrm{NOCF}_{\mathrm{j}, \mathrm{t}}+$ & $\begin{array}{l}\text { operating cash flow } \\
\text { accruals manipulation } \\
\text { real earnings management }\end{array}$ \\
\hline 5 & $\mathrm{NI}_{\mathrm{j}, \mathrm{t}+1}=\beta_{0}+\beta_{1} \mathrm{ACCR}_{\mathrm{j}, \mathrm{t}}+\beta_{2} \mathrm{AOCF}_{\mathrm{j}, \mathrm{t}}+\beta_{3} \mathrm{NOCF}_{\mathrm{j}, \mathrm{t}}+\epsilon_{\mathrm{j}, \mathrm{t}}$ & $\begin{array}{l}\text { operating cash flow } \\
\text { real earnings management }\end{array}$ \\
\hline 6 & $\mathrm{NI}_{\mathrm{j}, \mathrm{t}+1}=\beta_{0}+\beta_{1} \mathrm{NMNI}_{\mathrm{j}, \mathrm{t}}+\beta_{2} \mathrm{AOCF}_{\mathrm{j}, \mathrm{t}}+\beta_{3} \mathrm{DAC}_{\mathrm{j}, \mathrm{t}}+\epsilon_{\mathrm{j}, \mathrm{t}}$ & $\begin{array}{l}\text { accruals manipulation } \\
\text { real earnings management }\end{array}$ \\
\hline
\end{tabular}

\section{Results}

\subsection{Descriptive Statistics}

The empirical equations developed in this section derive from the properties of the accural and operating cash flow components of earnings. Table 3 provides descriptive evidence related to these components.

According to Table 3, we find that net incomes of most observations are positive, accounted for $64.984 \%$ of the sample. The maximum value of these observations is of 4.953 times former total assets and the minimum value of the loss amounted to 3.948 times of the former total assets. The evidence shows the variance among net incomes of firm years. By the components of net income of Table 3, the means and medians of net income of observations are negative. However, the ones of cash flow of observations are positive.

Table 3. Descriptive statistics

\begin{tabular}{lcccccc}
\hline Variables & Mean & Std dev. & Median & Max. & Min. & \% Postiive \\
\hline Net income (NI) & 0.001 & 0.445 & 0.039 & 4.953 & -3.948 & 64.984 \\
Operating cash flow (OCF) & 0.073 & 0.121 & 0.064 & 0.872 & -1.863 & 82.152 \\
Total accruals (ACCR) & -0.071 & 0.435 & -0.029 & 4.885 & -4.085 & 36.668 \\
Nondiscretionary accruals (NDAC) & -0.033 & 0.503 & -0.011 & 5.013 & -4.462 & 47.121 \\
Discretionary accruals (DAC) & -0.038 & 0.226 & -0.016 & 1.871 & -1.743 & 44.342 \\
Nondiscretionary income (NDNI) & 0.040 & 0.540 & 0.047 & 5.081 & -4.511 & 59.271 \\
$\begin{array}{l}\text { Abnormal cash flow from real activities manipulation } \\
\text { (AOCF) }\end{array}$ & 0.015 & 0.113 & 0.011 & 0.830 & -1.634 & 56.616 \\
$\begin{array}{l}\text { Cash flow from operation before real activities manipulation } \\
\text { (NOCF) }\end{array}$ & 0.057 & 0.061 & 0.051 & 0.568 & -1.611 & 94.545 \\
Nonmanipulated net income (NMNI) & 0.024 & 0.501 & 0.040 & 5.044 & -4.378 & 59.966 \\
\hline
\end{tabular}

Note: The original sample consists of 6,476 firm-years during the time period 2002-2011. All variables are scaled by lagged total assets. 


\subsection{Earnings Components and Future Profotability}

This study regresses the components of earnings and compares the relative magnitudes of their coefficients to investigate the explanatory power of these components in forecasting future profitability.

Panel A of Table 4 displays results of multivariate regressions of variables appearing in Table 2. The statistical results of adjusted R-square show that each individual component of earnings has a significantly positive impact on future profitability, except for discretionary accrual (DAC) which demonstrates a negative impact on future profitability. Panel A provides evidence that net income explains returns better than either nondiscretionary income or operating cash flow for covering a larger extent.

We conduct a statistical test via separately comparing adjust R-square of these models to determine which model has more explanatory power in future profitability. Panel C presents results of a likelihood ratio test suggested by Vuong (1989) to investigate which model can better explain the dependent variables. All the comparisons in Panel C are statistically significant at the 0.01 level or better. Particularly, the increased explanatory power of Model 7 wins over Model 1 with a 9.103 incremental R-square percentage, implying that the information content of operating cash flow is essential for the prediction of future profitability. Both Model 2 and Model 3 are related with the manipulation components of accruals. The adjusted R-square percentage of Model 2, 13.648\%, is higher than that of Model 3, $11.037 \%$. The results indicate that operating cash flow and nondiscretionary accruals provide more incremental information than nondiscretionary income and show the consistency from the comparisons of Model 4 and Model 6.

Panel A of Table 4 analyzes the incremental information effects of the discretionary and nondiscretionary components of net income by regressing returns on earning components in multivariate models. In Model 1, we decompose earning into two categories: operating cash flow and accruals. Model 2 examines further as it divides accruals into discretionary (DAC) and nondiscretionary (NDAC) ones. The incremental R-square of Model 2 is $3.057 \%$, which is significantly higher than regressing returns in Model 1, a model merely treats the contents of operating cash flow and accruals as a whole. After comparing these two models, we find that the components of accruals provide more information about future profitability. The comparison of Model 4 and Model 5 reveals the same results.

The next stage of the analysis investigates the incremental information content of real earning management by conducting a regression of returns on earning components in Model 2 and Model 4. As shown in Model 4 on Table 2, earnings consist of two manipulation components: abnormal cash flow from real activities manipulation (AOCF) and operating cash flow before real activities manipulation (NOCF). The adjusted R-square of Model 4 increases by $4.396 \%$, compared with the one of Model 1 . Then we compare it with Model 5, which shows the decreased adjusted R-square percentage by $4.358 \%$. We thus conclude that the regressing returns on the components of accruals of Model 4 have more explanatory power for future profitability. However, the results of comparing Model 4\&2, Model $6 \& 3$, Model $5 \& 1$ on Panel $\mathrm{C}$ show that the components of real earnings management have less explanatory power for future profitability.

Table 4. Regression of net income $(\mathrm{t}+1)$ on earnings components

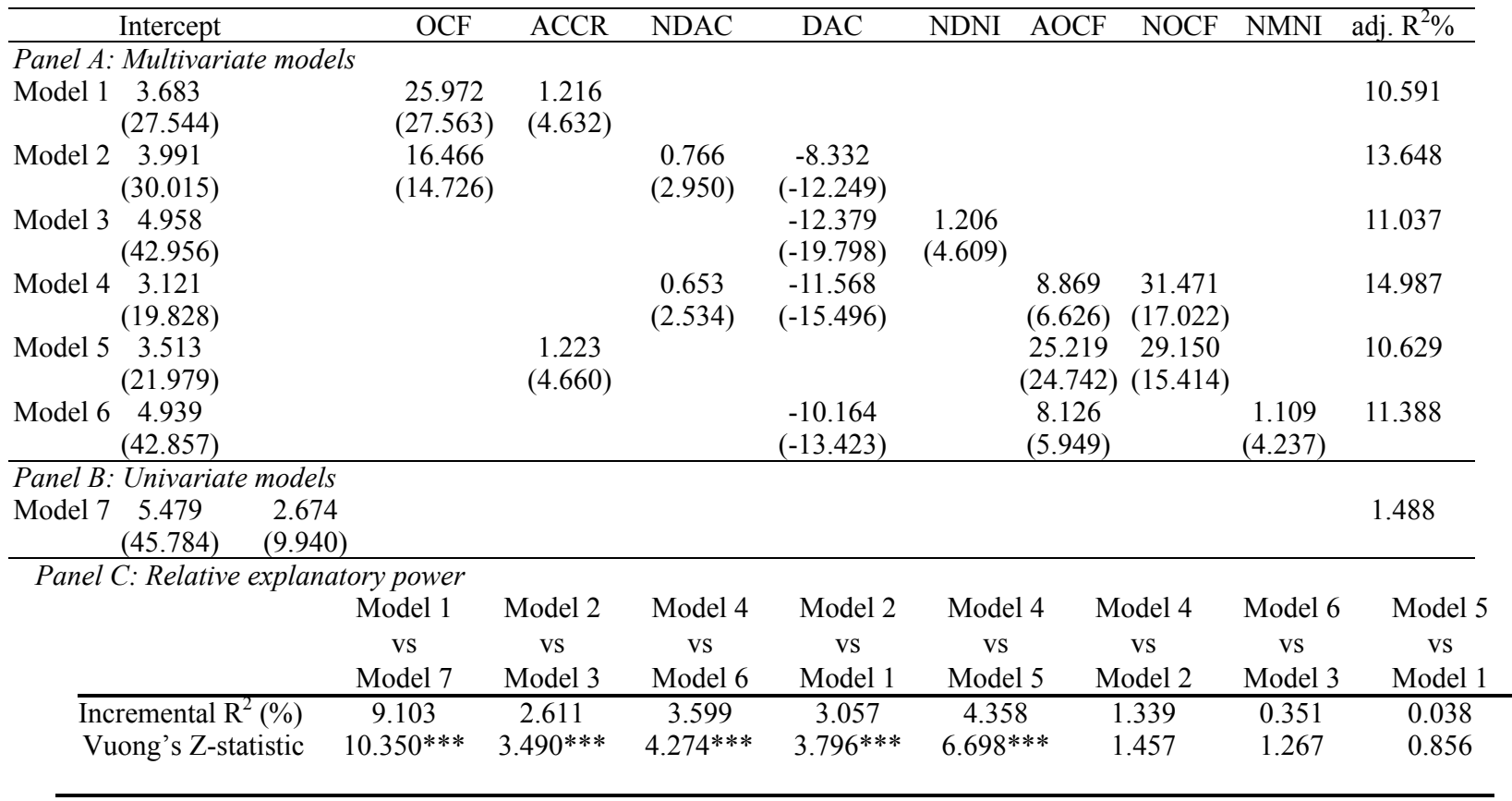


Note:

1. The dependent variables are operating cash flows $(O C F)$, total accruals $(A C C R)$, nondiscretionary accruals $(N D A C)$, discretionary accruals $(D A C)$, nondiscretionary income $(N D N I)$, Abnormal cash flow from real activities manipulation $(A O C F)$, cash flow before real activities manipulation $(N O C F)$, and nonmanipulation net income $(N M N I)$. Nondiscretionary and discretionary accruals are determined by the cross-sectional variation of Jones' (1991) model. Nondiscretionary income is the sum of operating cash flows and nondiscretionary accruals. Abnormal cash flow from real activities manipulation is according to Roychowdhury's (2006) model. All variables of earnings components are deflated by totals at the beginning of the period. Incremental R-square refers to the increase in explanatory power with the inclusion discretionary accruals. Figures in parentheses denote t-statistics. The applied likelihood ratio test, Vuong's Z-statistic, is proposed by Vuong (1989) for non-nested model selection. The reported statistic measures statistical significance of the increase explanatory power by including discretionary accruals and real earnings management.

2. $*, * *, * * *$ indicate one-tailed significance at the $0.01,0.05$. and 0.10 level, respectively.

\subsection{Information of Earnings Components after Deleting Extreme Earnings Management}

To avoid biases caused by extreme values in our prediction, this study first excludes the extreme $5 \%$ of abnormal operating cash flow/discretionary accruals, then it tests the explanatory power of different components in the future. The elimination of extreme 5\% results in a loss of 324 observations and reduces our final samples to 6,152 firm-years. Table 5 illustrates results exemplifying the increased explanatory power of all components of earnings.

The results imply that the activities of extreme earnings management would decrease the explanatory power of net income to predict future earnings. It turns out that the quality of financial information in earning announcements is relatively low. This analysis also suggests that excessive earnings manipulation would decrease the explanatory power of financial information to predict profitability. Accordingly, investors would misjudge the value of a company and may therefore misprice its stocks.

Table 5. Comparison explanatory power of earnings components on future net income after deleting extreme real earnings management

\begin{tabular}{|c|c|c|c|c|}
\hline Dependent variables & $\begin{array}{r}\operatorname{adj} R^{2}(\%) \text { of } \\
\text { All }\end{array}$ & $\begin{array}{r}\text { adj } R^{2}(\%) \text { of excluding } \\
\text { extreme } 5 \%\end{array}$ & $\begin{array}{r}\text { Incremental } \\
\mathrm{R}^{2}(\%) \\
\end{array}$ & $\begin{array}{r}\text { Abs Vuong's } \\
\text { Z-statistic } \\
\end{array}$ \\
\hline \multicolumn{5}{|c|}{$\begin{array}{l}\text { Panel A: deleting extreme } 5 \% \text { AOCF } \\
\text { Independent variable }: N I\end{array}$} \\
\hline NI & 1.488 & 1.580 & 0.092 & 1.025 \\
\hline OCF, ACCR & 10.591 & 16.511 & 5.920 & $7.045 * * *$ \\
\hline OCF,NDAC,DAC & 13.648 & 18.34 & 4.692 & $5.315 * * *$ \\
\hline DAC,NDNI & 11.037 & 12.815 & 1.778 & $1.964 *$ \\
\hline NDAC,DAC,AOCF,NOCF & 14.987 & 19.225 & 4.238 & $5.015 * * *$ \\
\hline ACCR,AOCF,NOCF & 10.629 & 16.635 & 6.006 & $7.158 * * *$ \\
\hline NMNI,AOCF,DAC & 11.388 & 14.137 & 2.749 & $3.105 * * *$ \\
\hline \multicolumn{5}{|l|}{ Independent variable: $\mathrm{NI}_{t+2}$} \\
\hline $\mathrm{NI}$ & 0.853 & 0.902 & 0.049 & 1.028 \\
\hline OCF, ACCR & 10.881 & 17.188 & 6.307 & $8.024 * * *$ \\
\hline OCF,NDAC,DAC & 14.404 & 18.854 & 4.450 & $6.105 * * *$ \\
\hline DAC,NDNI & 10.613 & 11.923 & 1.310 & 1.456 \\
\hline NDAC,DAC,AOCF,NOCF & 14.83 & 18.958 & 4.128 & $3.048 * * *$ \\
\hline ACCR,AOCF,NOCF & 10.924 & 17.243 & 6.319 & $8.158 * * *$ \\
\hline NMNI,AOCF,DAC & 11.855 & 14.618 & 2.763 & $3.109 * * *$ \\
\hline \multicolumn{5}{|l|}{ Independent variable: $\mathrm{NI}_{t+3}$} \\
\hline $\mathrm{NI}$ & 0.946 & 0.970 & 0.024 & 0.899 \\
\hline $\mathrm{OCF}, \mathrm{ACCR}$ & 11.323 & 17.191 & 5.868 & $8.021 * * *$ \\
\hline OCF,NDAC,DAC & 15.934 & 19.147 & 3.213 & $3.015 * * *$ \\
\hline DAC,NDNI & 11.796 & 12.305 & 0.509 & 0.956 \\
\hline NDAC,DAC,AOCF,NOCF & 16.033 & 19.163 & 3.130 & $3.468 * * *$ \\
\hline ACCR,AOCF,NOCF & 11.704 & 17.431 & 5.727 & $7.841 * * *$ \\
\hline NMNI,AOCF,DAC & 13.697 & 15.242 & 1.545 & 1.578 \\
\hline \multicolumn{5}{|c|}{$\begin{array}{l}\text { Panel B: deleting extreme } 5 \% \mathrm{DAC} \\
\text { Independent variable: } N I_{t+1}\end{array}$} \\
\hline $\mathrm{NI}$ & 1.488 & 0.919 & -0.569 & 1.025 \\
\hline OCF, ACCR & 10.591 & 8.389 & -2.202 & $3.054 * * *$ \\
\hline
\end{tabular}




\begin{tabular}{lrrrr}
\hline OCF,NDAC,DAC & 13.648 & 11.002 & -2.646 & $4.035 * * *$ \\
DAC,NDNI & 11.037 & 8.102 & -2.935 & $4.251 * * *$ \\
NDAC,DAC,AOCF,NOCF & 14.987 & 12.346 & -2.641 & $2.986 * * *$ \\
ACCR,AOCF,NOCF & 10.629 & 8.513 & -2.116 & $3.751 * * *$ \\
NMNI,AOCF,DAC & 11.388 & 8.542 & -2.846 & $3.785 * * *$ \\
Independent variable: $N_{t+2}$ & & & & \\
NI & 0.853 & 0.828 & -0.025 & 0.865 \\
OCF, ACCR & 10.881 & 20.838 & 9.957 & $12.032 * * *$ \\
OCF,NDAC,DAC & 14.404 & 23.382 & 8.978 & $10.325 * * *$ \\
DAC,NDNI & 10.613 & 16.721 & 6.108 & $8.105 * * *$ \\
NDAC,DAC,AOCF,NOCF & 14.83 & 23.691 & 8.861 & $11.035 * * *$ \\
ACCR,AOCF,NOCF & 10.924 & 22.534 & 11.610 & $15.105 * * *$ \\
NMNI,AOCF,DAC & 11.855 & 22.105 & 10.250 & $12.015 * * *$ \\
Independent variable: $N I_{t+3}$ & & & & \\
NI & 0.946 & 5.348 & 4.402 & $3.025 * * *$ \\
OCF, ACCR & 11.323 & 27.071 & 15.748 & $18.035 * * *$ \\
OCF,NDAC,DAC & 15.934 & 25.98 & 10.046 & $15.024 * * *$ \\
DAC,NDNI & 11.796 & 5.084 & -6.712 & $7.015 * * *$ \\
NDAC,DAC,AOCF,NOCF & 16.033 & 24.518 & 8.485 & $10.241 * * *$ \\
ACCR,AOCF,NOCF & 11.704 & 25.613 & 13.909 & $16.012 * * *$ \\
NMNI,AOCF,DAC & 13.697 & 21.341 & 7.644 & $9.105 * *$ \\
\hline
\end{tabular}

Note:

1. The original sample consists of 6,476 firm-years during the period 2002-11. Observation that extreme 5\% of abnormal operating cash flow/ discretionary accruals are excluded. This results in a loss of 324 observations reducing the final sample to 6,152 firm-years. The independent variables are net income (NI), operating cash flows $(O C F)$, total accruals $(A C C R)$, nondiscretionary accruals $(N D A C)$, discretionary accruals $(D A C)$, abnormal cash flow from real activities manipulation $(A O C F)$, and cash flow before real activities manipulation (NOCF). Nondiscretionary and discretionary accruals are determined by the cross-sectional variation of Jones' (1991) model. Nondiscretionary income is the sum of operating cash flows and nondiscretionary accruals. Abnormal cash flow from real activities manipulation is according to Roychowdhury's (2006) model. All variables of earnings components are deflated by totals at the beginning of the period. Incremental R-square refers to the increase in explanatory power with the inclusion discretionary accruals. The applied likelihood ratio test, Vuong's Z-statistic, is proposed by Vuong (1989) for non-nested model selection. The reported statistic measures statistical significance of the increase explanatory power by including discretionary accruals and real earnings management.

2. $*, * *, * * *$ indicate one-tailed significance at the $0.01,0.05$. and 0.10 level.

\subsection{Explanatory Power of Information Transfer by Firm Characteristics}

Wang (2014) and Asthana and Mishra (2001) indicate that firm characteristic determinates the firm's production and disseminates its information prior to earnings announcement in light of the hypothesis of differential information.

According to their hypothesis, investors make more profits from information announcement of large companies than that of small companies. This differential information hypothesis implies that earnings announcement of large firms conveys more information about the economy and industry conditions. However, earnings disclosures of small firms contain more "unexpected" information, which leads to more market adjustments.

On the other hand, the earning quality hypothesis (Healy and Palepu, 2001; Choi and Salamon, 1989) argues that the quality of earnings information from smaller companies is usually superior to that from larger companies. Based on previous researches, this study further examines the explanatory power of earning components between large and small firms.

In Table 6, we observe that if we use only the current period's net income to explain future profit, the explanatory power of information from large companies is not significantly higher than small companies. Conversely, it turns out that the future net income of large companies is significantly higher than the explanatory power of a small company; as a result, operating cash flow and accruals compose the current earning. The evidence shows that the content of operating cash flows from large companies provides more information to predict future profitability.

This study further examines the explanatory power of operation cash flow (OCF) and accruals components by disassembling the accruals into nondiscretionary (NDAC) and discretionary (DAC) components to predict future earnings. The acquired evidence indicates that the informational contents of OCF, NDAC and DAC from large 
companies have significant higher explanatory powers. The next stage of our analysis dismantles operating cash flow into abnormal cash flow from real activities manipulation (AOCF) and cash flow from operation before real activities manipulation (NOCF). The results demonstrate that the informational content of real activities from large companies possesses more explanatory power than the one of small companies. All the results discussed above suggest that information contents of earnings from large companies indeed provide more explanatory power.

Table 6. Comparison explanatory power of earnings components on future net income with firm size

\begin{tabular}{lrrrr}
\hline Dependent variables & $\begin{array}{r}\text { adj } \mathrm{R}^{2}(\%) \text { of } \\
\text { small firms }\end{array}$ & $\begin{array}{r}\text { adj } \mathrm{R}^{2}(\%) \text { of } \\
\text { large firms }\end{array}$ & $\begin{array}{r}\text { Incremental } \\
\mathrm{R}^{2}(\%)\end{array}$ & $\begin{array}{r}\text { Abs Vuong's } \\
\text { Z-statistic }\end{array}$ \\
\hline Panel A: regression of $\mathrm{NI}_{t+1}$ on earnings components & 1.305 & 1.658 & 0.353 & 1.025 \\
$\mathrm{NI}$ & 12.035 & 15.538 & 3.503 & $4.057 * * *$ \\
OCF, ACCR & 14.032 & 17.248 & 3.216 & $3.986 * * *$ \\
OCF,NDAC,DAC & 13.245 & 16.215 & 2.970 & 3.142 \\
DAC,NDNI & 17.025 & 19.248 & 2.223 & $2.867 * * *$ \\
NDAC,DAC,AOCF,NOCF & 12.068 & 15.158 & 3.090 & $2.974 * * *$ \\
ACCR,AOCF,NOCF & 14.065 & 17.125 & 3.060 & $3.041 * * *$ \\
NMNI,AOCF,DAC & & & \\
Panel B: regression of $N_{t+2}$ on earnings components & & & \\
NI & 1.024 & 1.211 & 0.187 & 0.458 \\
OCF, ACCR & 11.867 & 14.025 & 2.158 & $2.428 * * *$ \\
OCF,NDAC,DAC & 13.986 & 17.027 & 3.041 & $4.058 * * *$ \\
DAC,NDNI & 12.953 & 15.482 & 2.529 & $2.851 * * *$ \\
NDAC,DAC,AOCF,NOCF & 16.867 & 19.035 & 2.168 & $3.105 * * *$ \\
ACCR,AOCF,NOCF & 11.057 & 14.851 & 3.794 & $4.105 * * *$ \\
NMNI,AOCF,DAC & 13.527 & 16.527 & 3.000 & $3.045 * * *$ \\
Panel C: regression of $N I_{t+3}$ on earnings components & & & \\
NI & 0.864 & 1.024 & 0.160 & 1.005 \\
OCF, ACCR & 11.657 & 13.085 & 1.428 & 1.589 \\
OCF,NDAC,DAC & 12.567 & 16.957 & 4.390 & $4.959 * * *$ \\
DAC,NDNI & 12.524 & 15.024 & 2.500 & $3.245 * * *$ \\
NDAC,DAC,AOCF,NOCF & 15.489 & 18.098 & 2.609 & $4.012 * * *$ \\
ACCR,AOCF,NOCF & 10.958 & 14.005 & 3.047 & $5.012 * * *$ \\
NMNI,AOCF,DAC & 13.024 & 15.845 & 2.821 & $4.012 * * *$ \\
\hline
\end{tabular}

Note:

1. The independent variables are net income $(N I)$, operating cash flows $(O C F)$, total accruals (ACCR), nondiscretionary accruals (NDAC), discretionary accruals $(D A C)$, abnormal cash flow from real activities manipulation $(A O C F)$, and cash flow before real activities manipulation $(N O C F)$. Nondiscretionary and discretionary accruals are determined by the cross-sectional variation of Jones' (1991) model. Nondiscretionary income is the sum of operating cash flows and nondiscretionary accruals. Abnormal cash flow from real activities manipulation are determined is according to Roychowdhury's (2006) model. All variables of earnings components are deflated by totals at the beginning of the period. Incremental R-square refers to the increase in explanatory power with the inclusion discretionary accruals. The applied likelihood ratio test, Vuong's Z-statistic, is proposed by Vuong (1989) for non-nested model selection. The reported statistic measures statistical significance of the increase explanatory power from inclusion of discretionary accruals and real earnings management.

2. $* * *, * * *$ indicate one-tailed significance at the $0.01,0.05$. and 0.10 level.

\subsection{Compare the Explanatory Power of Panel Regression and OLS Regression}

For regression models, researchers refer to general regression model, tracking-data regression model (panel regression model), and other types. Since most accounting researchers have adopted general regression model, while some economic factors impacting on financial results may vary across companies, simply applying the general regression model to regress the earnings components' effects will be unable to correctly estimate their impacts. The 
panel regression model, which contains both cross-sectional and time series data analysis, allows researchers to mix cross-sectional and time series of economic phenomena simultaneously. Furthermore, the panel model can not only increase the degree of freedom of the samples, but also reduce the problems caused by missing variables via combining the common cross-sectional data with time series information.

To examine the explanatory powers of these two regression models, our study compares the results through regressing different components of earnings by both OSL and Panel regression models. Table 7 illustrates the results of Vuong test and shows no significant difference between two models when we use merely current income to predict future profitability. As our analysis dismantles earnings into information contents including the components of operating cash flow, accruals manipulation, as Ill as real earnings management, then all models yield regressing results of $Z$ value from 2.012 to 4.069 , at the $10 \%$ significance level, which are significantly positive. Therefore, according to Vuong test results, we find that panel regression model is better to predict future profitability.

Table 7. Comparison explanatory power of earnings components on future net income with estimate model

\begin{tabular}{lrrrc}
\hline Dependent variables & $\begin{array}{r}\text { adj } \mathrm{R}^{2}(\%) \text { of } \\
\text { OLS regression }\end{array}$ & $\begin{array}{r}\text { adj } \mathrm{R}^{2}(\%) \text { of } \\
\text { Panel regression }\end{array}$ & $\begin{array}{r}\text { Incremental } \\
\mathrm{R}^{2}(\%)\end{array}$ & $\begin{array}{r}\text { Abs Vuong's } \\
\text { Z-statistic }\end{array}$ \\
\hline Panel A: regression of $\mathrm{NI}_{t+1}$ on earnings components & & & \\
NI & 1.488 & 1.735 & 0.247 & 1.504 \\
OCF, ACCR & 10.591 & 13.539 & 2.948 & $3.158 * * *$ \\
OCF,NDAC,DAC & 13.648 & 16.245 & 2.597 & $3.428 * * *$ \\
DAC,NDNI & 11.037 & 13.587 & 2.550 & $2.587 * * *$ \\
NDAC,DAC,AOCF,NOCF & 14.987 & 18.025 & 3.038 & $4.015 * * *$ \\
ACCR,AOCF,NOCF & 10.629 & 13.240 & 2.611 & $2.886 * * *$ \\
NMNI,AOCF,DAC & 11.388 & 13.585 & 2.197 & $1.996 * *$ \\
Panel B: regression of $N I_{t+2}$ on earnings components & & & \\
NI & 0.853 & 1.621 & 0.768 & 1.024 \\
OCF, ACCR & 10.881 & 13.024 & 2.143 & $3.015 * * *$ \\
OCF,NDAC,DAC & 14.404 & 17.205 & 2.801 & $3.486 * * *$ \\
DAC,NDNI & 10.613 & 13.621 & 3.088 & $3.105 * * *$ \\
NDAC,DAC,AOCF,NOCF & 14.830 & 17.973 & 3.143 & $4.015 * * *$ \\
ACCR,AOCF,NOCF & 10.924 & 14.021 & 3.097 & $3.485 * * *$ \\
NMNI,AOCF,DAC & 11.855 & 14.850 & 2.995 & $3.158 * * *$ \\
Panel C: regression of $N I_{t+3}$ on earnings components & & & \\
NI & 0.946 & 1.423 & 0.477 & 0.989 \\
OCF, ACCR & 11.323 & 13.248 & 1.925 & $2.012 *$ \\
OCF,NDAC,DAC & 15.934 & 18.021 & 2.087 & $2.325 * *$ \\
DAC,NDNI & 11.796 & 14.201 & 2.405 & $3.024 * * *$ \\
NDAC,DAC,AOCF,NOCF & 16.033 & 19.125 & 3.092 & $4.069 * * *$ \\
ACCR,AOCF,NOCF & 11.704 & 14.521 & 2.817 & $2.983 * * *$ \\
NMNI,AOCF,DAC & 13.697 & 15.883 & 2.186 & $2.558 * * *$ \\
\hline
\end{tabular}

Note:

1. The independent variables are net income $(N I)$, operating cash flows $(O C F)$, total accruals (ACCR), nondiscretionary accruals $(N D A C)$, discretionary accruals $(D A C)$, abnormal cash flow from real activities manipulation $(A O C F)$, and cash flow before real activities manipulation $(N O C F)$. Nondiscretionary and discretionary accruals are determined by the cross-sectional variation of Jones' (1991) model. Nondiscretionary income is the sum of operating cash flows and nondiscretionary accruals. Abnormal cash flow from real activities manipulation are determined is according to Roychowdhury's (2006) model. All variables of earnings components are deflated by totals at the beginning of the period. Incremental R-square refers to the increase in explanatory power with the inclusion discretionary accruals. The applied likelihood ratio test, Vuong's Z-statistic, is proposed by Vuong (1989) for non-nested model selection. The reported statistic measures statistical significance of the increase explanatory power from inclusion of discretionary accruals and real earnings management.

2. $*, * *, * * *$ indicate one-tailed significance at the $0.01,0.05$. and 0.10 level. 


\subsection{Quantile Regression}

Traditional regression results represent the concept of "average." However, at different earnings levels, the explanatory powers of earning components in future profits may be different, so traditional regression analysis may not be adequate. This study further conducts the Quantile Regression to examine five combinations of earning decompositions (Model 1-6) as shown in Table 8. Panel A of Table 8 reveals that, among all earning components, ACCR has significant positive impacts on both higher and lower quantiles of future earnings when we compare it with operating cash flow (OCF). Our analysis decomposes the ACCR into components NDAC and DAC. The results of Panel B and D show that DAC has significant negative impacts on future earnings, but NDAC has significant positive impacts on future earning regardless of higher or lower quantiles.

Panel C disassembles earning component into DAC and NDNI, which simultaneously reflects DAC's significant positive impacts while identifying that NDNI's significant positive impacts on future earnings only take place in higher or lower quantiles.

Table 8. Quantile regression

\begin{tabular}{|c|c|c|c|c|c|c|c|c|c|c|}
\hline \multicolumn{11}{|c|}{ Panel A: Model 1} \\
\hline & OLS & 0.1 & 0.2 & 0.3 & 0.4 & 0.5 & 0.6 & 0.7 & 0.8 & 0.9 \\
\hline \multirow[t]{2}{*}{ Constant } & $3.683 * * *$ & $-6.1373 * * *$ & $-1.5173 * * *$ & $0.8281 * * *$ & $2.1448 * * *$ & $3.5256 * * *$ & $5.0659 * * *$ & $6.9124 * * *$ & $9.3980 * * *$ & $13.4468 * * *$ \\
\hline & $(27.544)$ & $(-18.471)$ & $(-6.576)$ & $(4.884)$ & $(14.225)$ & $(24.003)$ & $(36.541)$ & (39.918) & $(55.562)$ & $(53.312)$ \\
\hline \multirow[t]{2}{*}{ OCF } & $25.972 * * *$ & $36.3469 * * *$ & $30.3284 * * *$ & $27.8655 * * *$ & $30.0634 * * *$ & $30.1906 * * *$ & $29.8841 * * *$ & $28.3822 * * *$ & $25.9485 * * *$ & $=21.9399 * * *$ \\
\hline & $(27.562)$ & (14.128) & $(15.290)$ & (13.253) & $(16.469)$ & (19.779) & $(23.435)$ & (19.568) & $(23.823)$ & (16.997) \\
\hline \multirow[t]{2}{*}{ ACCR } & $1.2159 * * *$ & $1.8528 * * *$ & $0.8866 * * *$ & $0.4918 * *$ & 0.3330 & 0.2595 & $0.3985 * *$ & $0.6152 * * *$ & $1.0497 * * *$ & $1.8980 * * *$ \\
\hline & $(4.632)$ & $(8.823)$ & $(4.326)$ & $(2.311)$ & $(1.460)$ & $(1.455)$ & $(2.335)$ & (3.263) & $(6.506)$ & $(9.386)$ \\
\hline adj R-square & 0.1059 & 0.0550 & 0.0505 & 0.0547 & 0.0626 & 0.0690 & 0.0732 & 0.0735 & 0.0764 & 0.0763 \\
\hline F stat. & 384.5075 & & & & & & & & & \\
\hline \multicolumn{2}{|l|}{ Quasi-LR stat. } & 233.9373 & 386.5666 & 581.9140 & 757.9137 & 807.2998 & 806.8058 & 671.8044 & 571.9062 & 351.0235 \\
\hline \multicolumn{11}{|c|}{ Panel B: Model 2} \\
\hline \multirow[t]{2}{*}{ Constant } & $3.9913 * * *$ & $-5.5355 * * *$ & $-1.1620 * * *$ & $1.0833 * * *$ & $2.4280 * * *$ & $3.8589 * * *$ & $5.4456 * * *$ & $7.4694 * * *$ & $9.7453 * * *$ & $=13.4292 * * *$ \\
\hline & 30.0149 & $(-16.051)$ & $(-5.017)$ & (6.777) & (15.558) & (26.408) & (34.906) & $(43.478)$ & (55.392) & $(62.425)$ \\
\hline \multirow[t]{2}{*}{$\mathrm{OCF}$} & $16.4661 * * *$ & $23.1156 * * *$ & $20.6081 * * *$ & $20.7060 * * *$ & $22.678 * * *$ & $21.9313 * * *$ & $21.3140 * * *$ & $17.6793 * * *$ & $16.2958 * * *$ & $13.4512 * * *$ \\
\hline & 14.7261 & $(6.753)$ & $(8.292)$ & $(10.540)$ & (11.163) & $(12.540)$ & (13.168) & (11.044) & (12.642) & $(10.016)$ \\
\hline \multirow[t]{2}{*}{ NDAC } & $0.7660 * * *$ & $1.3154 * * *$ & $0.5344 *$ & 0.2380 & -0.1090 & -0.1293 & 0.0751 & 0.2517 & $0.6490 * * *$ & $1.1917 * * *$ \\
\hline & 2.9498 & $(3.440)$ & $(1.890)$ & $(1.110)$ & $(-0.519)$ & $(-0.6990)$ & $(0.409)$ & $(1.321)$ & $(3.346)$ & $(5.575)$ \\
\hline \multirow[t]{2}{*}{ DAC } & $-8.3323 * * *$ & $-9.3533 * * *$ & $-7.5810 * * *$ & $6.3493 * * *$ & $-6.6080 * * *$ & $-6.274 * * *$ & $-6.059 * * *$ & $-6.8434 * * *$ & $-7.2251 * * *$ & $-7.5126 * * *$ \\
\hline & -12.2490 & $(-8.135)$ & $(-6.739)$ & $(-7.412)$ & $(-8.459)$ & $(-8.791)$ & $(-8.298)$ & $(-9.669)$ & $(-12.214)$ & $(-9.780)$ \\
\hline adj R-square & 0.1364 & 0.07146 & 0.06182 & 0.0656 & 0.0734 & 0.0804 & 0.0847 & 0.0883 & 0.0947 & 0.1030 \\
\hline F stat. & 342.1190 & & & & & & & & & \\
\hline \multicolumn{2}{|l|}{ Quasi-LR stat. } & 343.7353 & 464.9079 & 701.3239 & 893.0705 & 963.1518 & 908.0512 & 832.8783 & 715.7839 & 506.3617 \\
\hline \multicolumn{11}{|c|}{ Panel C: Model 3} \\
\hline \multirow[t]{2}{*}{ Constant } & $4.9580 * * *$ & $-4.3466 * * *$ & -0.0340 & $2.1257 * * *$ & $3.8575 * * *$ & $5.2540 * * *$ & $6.8332 * * *$ & $8.7093 * * *$ & $10.9866 * * *$ & $=14.5577 * * *$ \\
\hline & $(42.955)$ & $(-18.921)$ & $(-0.223)$ & $(19.020)$ & $(40.273)$ & (55.394) & $(61.587)$ & (76.801) & $(83.081)$ & (77.985) \\
\hline \multirow[t]{2}{*}{ DAC } & $-12.3788 * * *$ & $-14.9078 * * *$ & $-12.0824 * * *$ & $-11.5178 * * *$ & $-11.175 * * *$ & $-11.6231 * * *$ & $-11.8104 * * *$ & $-11.2965 * * *$ & $-11.1587 * * *$ & $-11.3124 * * *$ \\
\hline & $(-19379)$ & $(-16.858)$ & $(-13.802)$ & $(-12.700)$ & $(-14.043)$ & $(-15.250)$ & $(-15.688)$ & $(-18.611)$ & $(-18.698)$ & $(-17.925)$ \\
\hline \multirow[t]{2}{*}{ NDNI } & $1.2058 * * *$ & $\quad 1.2700 * * *$ & $0.5933 * *$ & 0.3035 & 0.2556 & 0.1977 & 0.2573 & $0.6735 * * *$ & $0.9149 * * *$ & $1.4550 * * *$ \\
\hline & $(4.608)$ & $(3.7289)$ & $(2.116)$ & $(1.459)$ & (1.007) & $(0.670)$ & (1.017) & $(2.798)$ & $(4.528)$ & (7.759) \\
\hline adj R-square & 0.1103 & 0.0568 & 0.0433 & 0.0416 & 0.0468 & 0.0527 & 0.0568 & 0.0641 & 0.0746 & 0.0881 \\
\hline F stat. & 402.472 & & & & & & & & & \\
\hline Quasi-LR stat. & & 279.0014 & 335.0440 & 411.2261 & 533.6512 & 598.7098 & 547.7705 & 594.6238 & 555.3833 & 414.9777 \\
\hline
\end{tabular}


Table 8 (Count.)

\begin{tabular}{|c|c|c|c|c|c|c|c|c|c|c|}
\hline \multicolumn{11}{|c|}{ Panel D: Model 4} \\
\hline & OLS & 0.1 & 0.2 & 0.3 & 0.4 & 0.5 & 0.6 & 0.7 & 0.8 & 0.9 \\
\hline \multirow[t]{2}{*}{ Constant } & $3.1207 * * *$ & $-6.4448 * * *$ & $-2.2456 * * *$ & 0.065 & $1.5726 * * *$ & $2.9770 * * *$ & $4.4511 * * *$ & $6.3371 * * *$ & $8.6645 * * *$ & $12.3139 * * *$ \\
\hline & (19.828) & $(-21.345)$ & $(-7.940)$ & $(0.313)$ & $(8.663)$ & $(15.698)$ & $(20.676)$ & $(35.728)$ & $(42.661)$ & $(45.986)$ \\
\hline \multirow[t]{2}{*}{ NDAC } & $0.6533 * *$ & $1.4985 * * *$ & $0.6030 * *$ & 0.1083 & 0.0425 & -0.1156 & 0.0083 & 0.1029 & $0.5011 * * *$ & $0.7784 * *$ \\
\hline & $(2.533)$ & $(6.410)$ & $(1.970)$ & $(0.468)$ & $(0.229)$ & $(-0.591)$ & $(0.034)$ & $(0.575)$ & $(2.661)$ & $(2.415)$ \\
\hline \multirow[t]{2}{*}{ DAC } & $-11.5683 * * *$ & $-10.6008 * * *$ & $-9.4885 * * *$ & $-8.9895 * * *$ & $-9.2002 * * *$ & $-9.6565 * * *$ & $-10.0237 * * *$ & $-11.027 * * *$ & $-11.1991 * * *$ & $-12.8024 * * *$ \\
\hline & $(-15.496)$ & $(-11.766)$ & $(-8.748)$ & $(-11.309)$ & $(-11.728)$ & $(-10.285)$ & $(-11.766)$ & $(-13.092)$ & $(-16.390)$ & $(-12.234)$ \\
\hline \multirow[t]{2}{*}{$\mathrm{AOCF}$} & $8.8687 * * *$ & $17.5279 * * *$ & $14.6080 * * *$ & $13.1126 * * *$ & $13.4026 * * *$ & $13.5279 * * *$ & $12.6901 * * *$ & $10.0798 * * *$ & $7.0740 * * *$ & $4.0849 * * *$ \\
\hline & $(6.625)$ & $(5.867)$ & $(5.776)$ & $(6.4655)$ & $(6.158)$ & $(5.830)$ & $(6.877)$ & $(6.266)$ & $(6.035)$ & $(2.719)$ \\
\hline \multirow[t]{2}{*}{$\mathrm{NOCF}$} & $31.4714 * * *$ & $43.7916 * * *$ & $42.6891 * * *$ & $39.6123 * * *$ & $38.5391 * * *$ & $37.5532 * * *$ & $38.2144 * * *$ & $36.4134 * * *$ & $33.8179 * * *$ & $29.2790 * * *$ \\
\hline & $(17.022)$ & $(12.574)$ & $(11.640)$ & $(14.202)$ & $(14.777)$ & $(13.807)$ & $(12.798)$ & $(17.0923)$ & $(15.195)$ & $(13.191)$ \\
\hline adj R-square & 0.1498 & 0.0776 & 0.0720 & 0.0776 & 0.0853 & 0.0919 & 0.0965 & 0.1017 & 0.1085 & 0.1153 \\
\hline F stat. & 286.3650 & & & & & & & & & \\
\hline \multicolumn{2}{|l|}{ Quasi-LR stat. } & 394.8018 & 556.6452 & 860.8125 & 1050.871 & 1103.837 & 1013.009 & 994.8058 & 840.1158 & 556.8804 \\
\hline \multicolumn{11}{|c|}{ Panel E: Model 5} \\
\hline \multirow[t]{2}{*}{ Constant } & $3.5134 * * *$ & $-6.5344 * * *$ & $-2.2734 * * *$ & 0.1736 & $1.6627 * * *$ & $3.0389 * * *$ & $4.6442 * * *$ & $6.4658 * * *$ & $9.1415 * * *$ & $13.3487 * * *$ \\
\hline & $(21.979)$ & $(-15.584)$ & $(-8.081)$ & $(0.847)$ & $(9.874)$ & $(15.397)$ & $(21.037)$ & $(33.430)$ & $(38.344)$ & $(45.099)$ \\
\hline \multirow[t]{2}{*}{$\mathrm{ACCR}$} & $1.2232 * * *$ & $1.8261 * * *$ & $1.0177 * * *$ & $0.5490 * *$ & $0.3792 *$ & 0.2531 & $0.3599 * *$ & $0.6326 * * *$ & $1.0801 * * *$ & $1.8589 * * *$ \\
\hline & $(4.660)$ & $(8.401)$ & $(4.158)$ & $(2.466)$ & $(1.825)$ & $(1.367)$ & $(2.059)$ & $(3.481)$ & $(6.162)$ & $(8.966)$ \\
\hline \multirow[t]{2}{*}{$\mathrm{AOCF}$} & $25.2186 * * *$ & $34.3502 * * *$ & $28.0601 * * *$ & $25.2670 * * *$ & $27.9337 * * *$ & $28.8854 * * *$ & $28.4889 * * *$ & $27.2182 * * *$ & $25.410 * * *$ & $21.8550 * * *$ \\
\hline & $(2.7421)$ & $(12.693)$ & $(15.054)$ & $(12.028)$ & $(15.710)$ & (19.169) & (19.782) & (19.111) & $(21.535)$ & $(15.545)$ \\
\hline \multirow[t]{2}{*}{$\mathrm{NOCF}$} & $29.1497 * * *$ & $46.950 * * *$ & $44.3741 * * *$ & $38.7870 * * *$ & $39.4615 * * *$ & $38.7882 * * *$ & $36.9890 * * *$ & $36.0422 * * *$ & $29.7607 * * *$ & $23.8185 * * *$ \\
\hline & $(15.413)$ & $(8.879)$ & $(13.032)$ & $(14.216)$ & $(16.645)$ & $(14.249)$ & (11.997) & $(15.478)$ & (11.648) & $(8.057)$ \\
\hline adj R-square & 0.1062 & 0.0564 & 0.0544 & 0.0589 & 0.0659 & 0.0710 & 0.0747 & 0.0753 & 0.0768 & 0.0762 \\
\hline F stat. & 257.6989 & & & & & & & & & \\
\hline \multicolumn{2}{|l|}{ Quasi-LR stat. } & 246.9943 & 421.3318 & 644.0494 & 808.9243 & 833.8866 & 815.0053 & 710.7237 & 575.1409 & 348.8591 \\
\hline \multicolumn{11}{|c|}{ Panel E: Model 6} \\
\hline \multirow[t]{2}{*}{ Constant } & $4.939 * * *$ & $-4.362 * * *$ & -0.129 & $2.110 * * *$ & $3.801 * * *$ & $5.236 * * *$ & 6.814 & $8.732 * * *$ & 10.948 & 14.484 \\
\hline & $(42.857)$ & $(-17.944)$ & $(-0.778)$ & $(18.517)$ & $(38.842)$ & $(54.552)$ & $(61.849)$ & $(76.634)$ & $(83.536)$ & $(72.142)$ \\
\hline \multirow[t]{2}{*}{ DAC } & $-10.164 * * *$ & $-12.148 * * *$ & $-10.397 * * *$ & $-9.470 * * *$ & $-9.497 * * *$ & $-9.604 * * *$ & -9.396 & $-8.818 * * *$ & -8.970 & -9.296 \\
\hline & $(-13.423)$ & $(-10.195)$ & $(-11.023)$ & $(-11.697)$ & $(-11.142)$ & $(-11.523)$ & $(-12.107)$ & $(-10.471)$ & $(-13.629)$ & $(-7.493)$ \\
\hline \multirow[t]{2}{*}{$\mathrm{AOCF}$} & $8.126 * * *$ & $10.778 * * *$ & $9.667 * * *$ & $7.677 * * *$ & $7.368 * * *$ & $7.264 * * *$ & 8.212 & $7.738 * * *$ & 7.016 & 6.340 \\
\hline & $(5.949)$ & $(3.163)$ & $(4.722)$ & $(5.029)$ & $(4.145)$ & $(4.3223)$ & $(5.334)$ & $(4.941)$ & $(6.733)$ & $(2.347)$ \\
\hline \multirow[t]{2}{*}{ NMNI } & $1.109 * * *$ & $1.301 * * *$ & $0.581 * *$ & $0.368 *$ & 0.149 & 0.064 & 0.202 & $0.541 * *$ & 0.974 & 1.514 \\
\hline & $(4.237)$ & $(4.021)$ & $(2.011)$ & $(1.715)$ & $(0.655)$ & $(0.240)$ & $(0.876)$ & $(2.476)$ & $(4.487)$ & $(8.790)$ \\
\hline adj R-square & 0.1139 & 0.0598 & 0.0458 & 0.0448 & 0.0496 & 0.0554 & 0.0601 & 0.0677 & 0.0778 & 0.0889 \\
\hline F stat. & 319.524 & & & & & & & & & \\
\hline Quasi-LR stat. & & 287.721 & 349.322 & 452.677 & 563.824 & 627.501 & 587.372 & 635.745 & 582.323 & 412.518 \\
\hline
\end{tabular}




\section{Conclusions}

We find that the components of operating cash flow and accuals have more explanatory power for predictability of future profitability. However, the ones of real earnings management reveal less explanatory power.

This study first applies univariate regressions of several alternative firm performance measures: NI, OCF, NDAC, DAC, NDNI, AOCF, NOCF and NMNI, respectively. Next, we examine the incremental information content of components of net income by regressing future net income on earnings' components in multivariate models. In order to assess the components' relative information content, our analysis pays attention to the explanatory power and slope coefficients and compares them with the regression results of future profitability.

In this research, we find evidence that net income explains returns better than considering either nondiscretionary income or operating cash flow. As shown in Panel A of Table 3, we use multivariate models to examine the incremental information effects of the discretionary and nondiscretionary components of net income by regressing returns on earning components. The comparison between Model 1 and Model 2 implies that the components of accruals provide more information content about future profitability. After comparing Model 2 and Model 3, we observe that operating cash flow and nondiscretionary accruals have more incremental information content than nondiscretionary income. Our next analysis stage investigates the incremental information content of real earning management by estimating regressing returns on earning components in Model 2 and Model 4. Compared with the decreased adjusted R-square percentage of Model 5, the regressing returns on components of accruals in Model 4 have more explanatory power for one enterprise's future profitability.

We also eliminate the extreme $5 \%$ observations and reduce our final samples to 6,152 firm-years. The results demonstrate increased explanatory power of all components of earnings and thus imply that the actions of extreme earnings management would decrease the explanatory power of net income for investors to predict future earnings. Moreover, our findings suggest that excessive earnings manipulation would decrease the explanatory power of financial information as well.

Our findings are consistent with the differential information hypothesis, which argues that earnings announcement of large firms conveys more information. To be more precise, the evidence of our study indicates that the future net income of large companies is significantly higher than the one of small companies as a result of decomposing the current earning into operating cash flow and accruals. The findings also suggest that studying the content of operating cash flows from large companies will provide more information to predict their future profitability. Consequently, the informational content of real activities from large companies has more explanatory power than the one of small companies.

In addition, this study compares the results by regressing different components of earnings via OSL and Panel regression models and it shows that there is no significant difference between OLS and Panel regressions, when we use only current income to predict future profitability. However, if we further analyze the data and dismantle earnings into information contents including operating cash flow, accruals manipulation as Ill as real earnings management, we can conclude that panel regression model is better to predict future profitability.

Finally, the results of the quantile regression in our study states that ACCR has significant positive impacts in both the higher and lower quantiles of future earnings. Our analysis then decomposes the ACCR into NDAC and DAC. Next, the regression yields results suggesting that DAC has significant negative impacts on future earnings; on the contrary, NDAC has significant positive impacts on future earning, whether in higher or lower quantiles. Furthermore, we disassemble earning components into DAC and NDNI and we notice that DAC remains its significant positive impacts, but NDNI generates significant positive impacts on future earnings only in higher or lower quantiles.

In sum, according to the discussions above, we find that the more visible the information content of earnings is, the more precise the prediction of future profitability can be.

\section{References}

Aono, J. Y., \& Guan, L. (2007). The impact of Sarbanes-Oxley act on cosmetic earnings management. Research in Accounting Regulation, 20, 205-215. http://dx.doi.org/10.1016/S1052-0457(07)00212-3

Asthana, S., \& Mishra, B. (2001). The differential information hypothesis, firm size, and earnings information transfer: an empirical investigation. Journal of Business Research, 37-47.

Badertscher, B. A. (2011, September). Overvaluation and the choice of alternative earnings management mechanisms. The Accounting Review, 86(5), 1491-1518. http://dx.doi.org/10.2308/accr-10092 
Bruns, W., \& Merchant, K. (1990). The dangerous morality of managing earnings. Management Accounting, 72 , $22-25$.

Bushee, B. J. (1998). The Influence of investors on myopic R\&D investment behavior. The Accounting Review, 73(3), 305-333.

Choi, S., \& Jeter, D. (1992). The effects of Qualified Audit Opinions on Earnings Response Coefficients. Journal of Accounting and Economics, 15, 229-247. http://dx.doi.org/10.1016/0165-4101(92)90019-X

Choi, S., \& Salamon, G. (1989). Accounting information and capital asset prices. Unpublished working paper, Dec. (Vanderbilt University, Nashville, TN).

Cohen, D. A., \& Zarowin, P. (2010). Accrual-based and real earnings management activities around seasoned equity offerings. Journal of Accounting and Economics, 50, 2-19. http://dx.doi.org/10.1016/j.jacceco.2010.01.002

Cohen, D. A., Dey, A., \& Lys, T. (2008). Real and accrual-based earnings management in the pre- and postSarbanes-Oxley periods. The Accounting Review, 83(3), 757-787.

Dechow, P. M., \& Ge, W. (2006). The persistence of earnings and cash flows and the role of special items: Implications for the accrual anomaly. Review of Accounting Studies, 11(2-3), 253-296.

Dechow, P. M., \& Skinner, D. J. (2000). Earnings management: Reconciling the views of accounting academics, practitioners, and regulators. Accounting Horizons, 14(2), 235-250.

Dechow, P. M., \& Sloan, R. G. (1991). Executive incentives and the horizon problem: An empirical investigation. Journal of Accounting and Economics, 14(1), 51-89. http://dx.doi.org/10.1016/0167-7187(91)90058-S

Dechow, P. M., Ge, W., \& Schrand, C. (2010). Understanding earning quality: A review of the proxies, their determinants and their consequences. Journal of Accounting and Economics, 50, 344-401.

Dechow, P. M., Sloan, R. G., \& Sweeney, A. P. (1996). Cause and consequence of earnings manipulation: An analysis of firms subject to enforcement actions by the SEC. Contemporary Accounting Research, 13, 1-36.

DeFond, M.L., \& Jiambalvo, J. (1994). Debt covenant effects and the manipulation of accruals. Journal of Accounting and Economics, 17, 145-176. http://dx.doi.org/10.1016/0165-4101(94)90008-6

Feng, M., Ge, W., Luo, S., \& Shevlin, T. (2011). Why do CFOs become involved in material accounting manipulation? Journal of Accounting and Economics, 51, 21-36.

Fudenberg, D., \& Tirole, J. (1995). A theory of income and dividend smoothing based on incumbency rents. Journalof Political Economy, 75-93. http://dx.doi.org/10.1086/261976

Graham, J.R., Harvey, C.R., \& Rajgopal, S. (2005). The economic implications of corporate financial reporting. Journal of Accounting and Economics, 40, 3-37. http://dx.doi.org/10.1016/j.jacceco.2005.01.002

Gunny, K. A. (2010). The relation between earnings management using real activities manipulation and future performance: Evidence from meeting earnings benchmarks. Contemporary Accounting Research, 27(3), 855-888. http://dx.doi.org/10.1111/j.1911-3846.2010.01029.x

Healy, P. M., \& Palepu, K. G. (2001). Information asymmetry, corporate disclosure, and the capital markets: A review of the empirical disclosure literature. Journal of Accounting and Economics, 31, 405-440.

Healy, P. M., \& Wahlen, J.M. (1999). A review of the earnings management literature and its implications for standard setting. Accounting Horizons, 13(4), 365-83. http://dx.doi.org/10.2308/acch.1999.13.4.365

Kang, S. A., \& Y. S. Kim. (2012). Effect of corporate governance on real activity-based earnings management: Evidence from Korea. Journal of Business Economics and Management, 13(1), 29-52.

Kasznik, R. (1999). On the association between voluntary disclosure and earnings management. Journal of Accounting Research, 33, 353-367.

Kothari, S. P., Leone, A. J., \& Wasley, C. E. (2005). Performance matched discretionary accrual measures. Journal of Accounting and Economics, 39, 163-197. http://dx.doi.org/10.1016/j.jacceco.2004.11.002

Lobo, G. J., \& Zhou, J. (2006). Did conservatism in financial reporting increase after the Sarbanes-Oxley act? Initial evidence. Accounting Horizons, 20(1), 57-73. http://dx.doi.org/10.2308/acch.2006.20.1.57

Roychowdhury, S. (2006). Earnings management through real activities manipulation. Journal of Accounting and Economics, 42, 335-370. http://dx.doi.org/10.1016/j.jacceco.2006.01.002

Sari, R. C., Warsono, S., \& Suryaningsum, Sri. (2010). Does investor protection affect the choice of earnings management methods through real activity manipulation and accrual manipulation? Asian comparison. Journal of Modern Accounting and Auditing, 6(6), 1-13. 
Schipper, K. (1989). Earnings management. Accounting Horizons, 3, 91-102.

Scholes, M., \& Williams, J. (1977). Estimating betas from nonsynchronous data. Journal of Financial Economics, 5(3), 309-328. http://dx.doi.org/10.1016/0304-405X(77)90041-1

Sloan, R. (1996). Do stock prices fully reflect information in accruals and cash flows about future earnings? The Accounting Review, 71(3), 289-315.

Subramanyam, K. R. (1996). The pricing of discretionary accruals. Journal of Accounting and Economics, 22, 249-281. http://dx.doi.org/10.1016/S0165-4101(96)00434-X

Taylor, G. K., \& Xu, R. Z. (2010). Consequences of real earnings management on subsequent operating performance. Research in Accounting Regulation, 22, 128-132. http://dx.doi.org/10.1016/j.racreg.2010.07.008

Visvanathan, G. (2008). Corporate governance and real earnings management. Academy of Accounting and Financial Studies, 12(1), 9-22.

Vuong, Q.H. (1989). Likelihood ratio tests for model selection and non-nested hypotheses. Econometrica, 307-333.

Wang, C. (2014). Accounting standards harmonization and financial statement comparability: Evidence from transnational information transfer. Journal of Accounting Research, 52(4), 955-992.

White, G., Sondhi, A., \& Fried, D. (1998). The analysis and use of financial statements. Hoboken, NJ: John Wiley \& Sons, Inc.

Xie, H. (2001). The mispricing of abnormal accruals. The Accounting Review, 76(3), 357-373.

Zang, A. Y. (2012, March). Evidence on the trade-off between real activities manipulation and accrual-based earnings management. The Accounting Review, 87(1), 675-703. http://dx.doi.org/10.2308/accr-10196

Zhou, J. (2007). Financial reporting after the Sarbanes-Oxley act: Conservative or less earnings management?. Research in Accounting Regulation, 20, 187-192. http://dx.doi.org/10.1016/S1052-0457(07)00210-X

\section{APPENDIX}

Table 1. Regression of net income $(\mathrm{t}+2)$ on earnings components

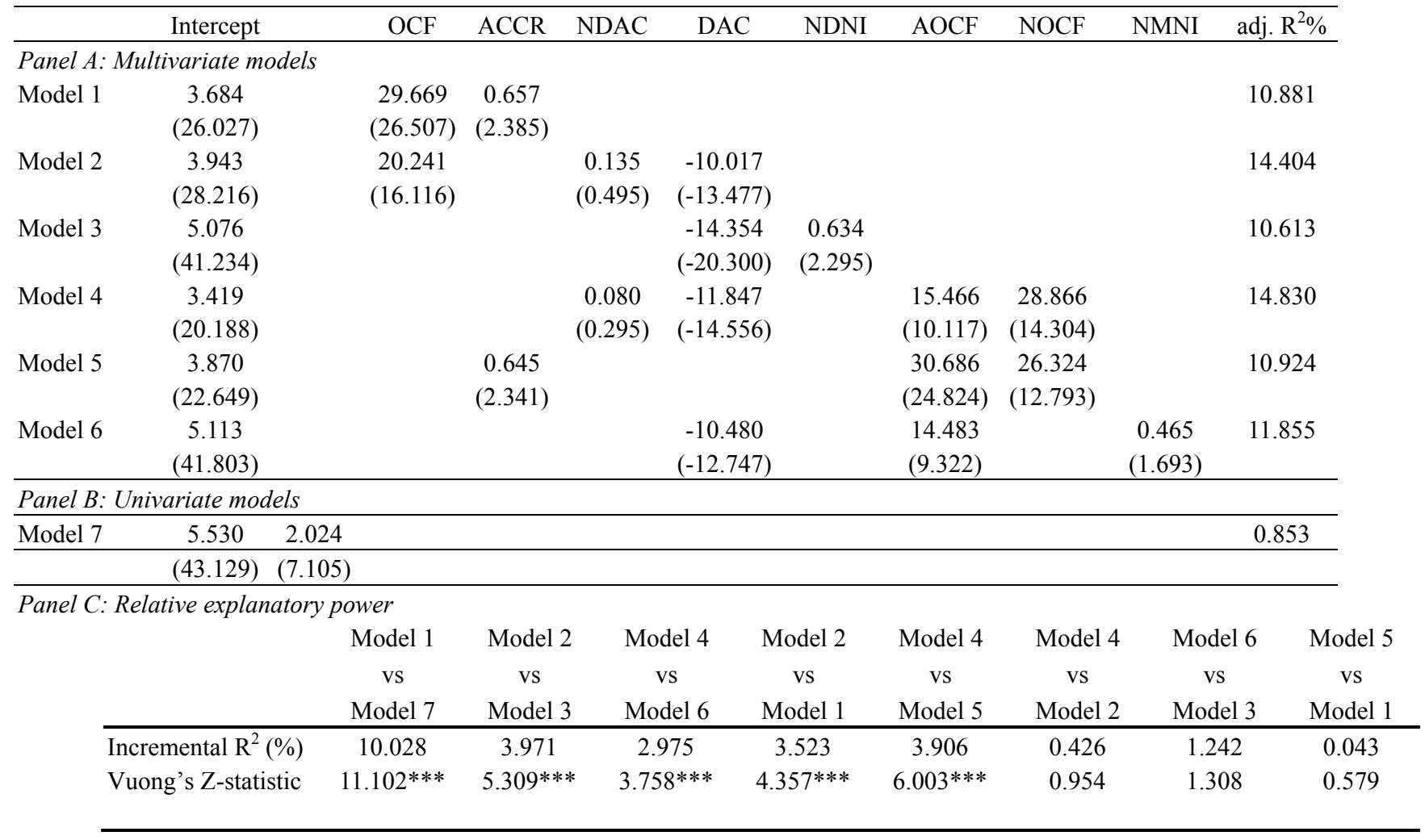


Note:

1. The dependent variables are operating cash flows $(O C F)$, total accruals $(A C C R)$, nondiscretionary accruals (NDAC), discretionary accruals $(D A C)$, nondiscretionary income (NDNI), Abnormal cash flow from real activities manipulation $(A O C F)$, cash flow before real activities manipulation $(N O C F)$, and nonmanipulation net income $(N M N I)$. Nondiscretionary and discretionary accruals are determined by the cross-sectional variation of Jones' (1991) model. Nondiscretionary income is the sum of operating cash flows and nondiscretionary accruals. Abnormal cash flow from real activities manipulation is according to Roychowdhury's (2006) model. All variables of earnings components are deflated by totals at the beginning of the period. Incremental R-square refers to the increase in explanatory power with the inclusion discretionary accruals. Figures in parentheses denote t-statistics. The applied likelihood ratio test, Vuong's Z-statistic, is proposed by Vuong (1989) for non-nested model selection. The reported statistic measures statistical significance of the increase explanatory power by including discretionary accruals and real earnings management.

2. *,**,*** indicate one-tailed significance at the $0.01,0.05$. and 0.10 level.

Table 2. Regression of net income $(\mathrm{t}+3)$ on earnings components

\begin{tabular}{|c|c|c|c|c|c|c|c|c|c|c|c|}
\hline & \multicolumn{2}{|l|}{ Intercept } & $\mathrm{OCF}$ & ACCR & NDAC & DAC & NDNI & $\mathrm{AOCF}$ & NOCF & NMNI & adj. $R^{2} \%$ \\
\hline \multicolumn{12}{|c|}{ Panel A: Multivariate models } \\
\hline Model 1 & $\begin{array}{c}3.930 \\
(27.144)\end{array}$ & & $\begin{array}{c}30.695 \\
(25.367)\end{array}$ & $\begin{array}{c}0.824 \\
(2.820)\end{array}$ & & & & & & & 11.323 \\
\hline Model 2 & $\begin{array}{c}4.165 \\
(29.397)\end{array}$ & & $\begin{array}{c}21.083 \\
(16.070)\end{array}$ & & $\begin{array}{c}0.321 \\
(1.122)\end{array}$ & $\begin{array}{c}-11.339 \\
(-14.466)\end{array}$ & & & & & 15.934 \\
\hline Model 3 & $\begin{array}{c}5.207 \\
(40.554)\end{array}$ & & & & & $\begin{array}{c}-15.380 \\
(-20.266)\end{array}$ & $\begin{array}{c}0.873 \\
(3.001)\end{array}$ & & & & 11.796 \\
\hline Model 4 & $\begin{array}{c}3.885 \\
(21.941)\end{array}$ & & & & $\begin{array}{c}0.293 \\
(1.024)\end{array}$ & $\begin{array}{c}-12.262 \\
(-14.293)\end{array}$ & & $\begin{array}{c}18.520 \\
(11.348)\end{array}$ & $\begin{array}{c}25.427 \\
(12.079)\end{array}$ & & 16.033 \\
\hline Model 5 & $\begin{array}{c}4.428 \\
(24.843)\end{array}$ & & & $\begin{array}{c}0.807 \\
(2.766)\end{array}$ & & & & $\begin{array}{c}33.743 \\
(24.701)\end{array}$ & $\begin{array}{c}22.217 \\
(10.339)\end{array}$ & & 11.704 \\
\hline Model 6 & $\begin{array}{c}5.361 \\
(41.936) \\
\end{array}$ & & & & & $\begin{array}{c}-10.897 \\
(-12.644) \\
\end{array}$ & & $\begin{array}{c}18.111 \\
(10.948) \\
\end{array}$ & & $\begin{array}{c}0.650 \\
(2.252)\end{array}$ & 13.697 \\
\hline \multicolumn{12}{|c|}{ Panel B: Univariate models } \\
\hline Model 7 & $\begin{array}{c}5.582 \\
(41.306)\end{array}$ & $\begin{array}{c}2.129 \\
(7.011)\end{array}$ & & & & & & & & & 0.946 \\
\hline Panel C: & e explano & $\begin{array}{l}\text { tory power } \\
\text { Model } 1 \\
\text { vs } \\
\text { Model } 7 \\
\end{array}$ & $\begin{array}{c}\text { Model } 2 \\
\text { vs } \\
\text { Model } 3\end{array}$ & & $\begin{array}{l}\text { odel } 4 \\
\text { vs } \\
\text { odel } 6 \\
\end{array}$ & $\begin{array}{l}\text { Model } 2 \\
\text { vs } \\
\text { Model } 1\end{array}$ & $\begin{array}{r}\text { Mod } \\
\text { Mod }\end{array}$ & 15 & $\begin{array}{l}\text { Model } 4 \\
\text { vs } \\
\text { Model } 2\end{array}$ & $\begin{array}{c}\text { Model } 6 \\
\text { vs } \\
\text { Model } 3\end{array}$ & $\begin{array}{c}\text { Model } 5 \\
\text { vs } \\
\text { Model } 1\end{array}$ \\
\hline Increment & & 9.103 & 4.138 & & 2.336 & 4.611 & 4.3 & & 0.099 & 1.901 & 0.381 \\
\hline Vuong's ? & & $0.350 * * *$ & $4.373 * * *$ & & $42 * * *$ & $4.827 * * *$ & 4.619 & $* * *$ & 0.648 & $1.726^{*}$ & 0.991 \\
\hline
\end{tabular}

Note:

1. The dependent variables are operating cash flows $(O C F)$, total accruals $(A C C R)$, nondiscretionary accruals $(N D A C)$, discretionary accruals $(D A C)$, nondiscretionary income $(N D N I)$, Abnormal cash flow from real activities manipulation $(A O C F)$, cash flow before real activities manipulation $(N O C F)$, and nonmanipulation net income $(N M N I)$. Nondiscretionary and discretionary accruals are determined by the cross-sectional variation of Jones' (1991) model. Nondiscretionary income is the sum of operating cash flows and nondiscretionary accruals. Abnormal cash flow from real activities manipulation is according to Roychowdhury's (2006) model. All variables of earnings components are deflated by totals at the beginning of the period. Incremental R-square refers to the increase in explanatory power with the inclusion discretionary accruals. Figures in parentheses denote t-statistics. The applied likelihood ratio test, Vuong's Z-statistic, is proposed by Vuong (1989) for non-nested model selection. The reported statistic measures statistical significance of the increase explanatory power by including discretionary accruals and real earnings management.

2. $* * *, * * *$ indicate one-tailed significance at the $0.01,0.05$. and 0.10 level. 